\title{
Children's Fantasy and Moroccan Social Issues in Francophone Film
}

\author{
$\mathrm{G}$ Ayuningtyas ${ }^{1}$ and $\mathrm{J}$ Tjahjani ${ }^{2}$ \\ $\{$ ghaisani.ayuningtyas@,ui.ac.id; 2joesana.tjahjani@ui.ac.id\} \\ ${ }^{12}$ French Department, Faculty of Humanities, Universitas Indonesia
}

\begin{abstract}
Fantasy is a pleasure and, in essence, is a way to escape from human's condition or reality by building a second life. In the film Ali Zaoua: Prince de la Rue, children's fantasy is shown through narrative and cinematographic aspects. This article focuses on the depiction of fantasy using a qualitative method and a textual approach. This analysis utilizes Greimas Actantial Model, film art by Boggs and Petrie, as well as structural semiotics by Barthes. The concept of fantasy by Rosemary Jackson is also utilized to deepen the analysis. The purpose of this study is to portray children's fantasy and social issues related to poverty and family in the movie Ali Zaoua: Prince de la Rue. The finding of the analysis shows that fantasies created by children, are a way to escape reality. The fantasies that were represented as children's imagination and becomes an antithesis to the fulfillment of real-life desires. This is related to the condition of street children who wish for a better livelihood.
\end{abstract}

Keywords: fantasy; Moroccan children's film; poverty; structural semiotic

\section{Introduction}

Francophone literature, including cinema, was first developed in Maghreb countries in the 1920s [1]. Since the 1990s, daring themes, such as national politics, were brought to the silver screen and was considered as a breakthrough in the Moroccan film industry. In general, the dominant theme in the Moroccan cinema was socio-realist drama in the context of the country's social issues [2]. Through didactic dialogues, socio-realist filmmakers portray the realities of Moroccan society and culture and debating current social issues in the country, for example the poverty [3]. The majority of poverty that happens in Morocco was due to economic factor, thus causing inequality to the society's living standard [4]. The inequality that happens in Morocco renders the lower-class society being seen differently than the rest of the society, including the street children [5]. A picture of street children's condition is depicted by the film Ali Zaoua: Prince de la Rue. The film is a Moroccan drama film that was directed by Nabil Ayouch and was first released on 25 November 2000. This film tells the story of four homeless children named Ali, Kwita, Omar, and Boubker who live in the streets. The story goes that the character Ali died from getting thrown a rock by another group of street children. The struggle of Ali's friends to bury Ali's body becomes the main story of the film. 
Two previous studies were done to the same corpus, but with a different focus of analysis. The first is an article titled Ali Zaoua: The Harsh Life of Street Children and the Poetics of Childhood (2007) by Josef Gugler [6]. In his article, Gugler discussed the portrayal of the harsh life of street children. The second is an article titled Sufi Mysticism and Dreams in Nabil Ayouch's Ali Zaoua, Prince of the Streets (2013) by Christa Jones [7] that focuses on symbols related to dreams and Sufi mysticism in the film. She also discussed fantasy in the film, but only as a background to support the focus of the study, that is the meaning in the film's symbols. For that reason, this article will focus on how children's fantasy is depicted and find the relevant social issues that are shown through narrative and cinematographic aspects. It aims to uncover the meaning behind the children's fantasy contained in the film.

\section{Research Method}

The method that will be used is a qualitative research method cinema theory with a textual approach. Cinema theory from Boggs and Petrie is used to strengthen the analysis of children's fantasy and social issues in the film Ali Zaoua: Prince de la Rue. Film is a mode of expression because it communicates visually through actions and gestures as well as verbally through intercharacter dialogues [8]. Film is a form of expression because it can be communicated visually. Cinema theory uncovers the narrative aspects and cinematography in this film. The theory is used to form sequences of the film, discuss backgrounds and characters, and read patterns through the signification of fantasy-related sequences in the film.

This study also utilizes Roland Barthes's structural semiotics theory that comprises denotation, connotation, myth, and ideology. Barthes developed de Saussure's linguistic concept into a study of signs. Signification happens in two folds. The signifier becomes one in the first layer, thus can form a signified in the second, and in the following layers, the signifier and the signified that has become unified forms a new signified that is an expansion of the signification. The first signifier is called denotation, while the second layer of signification is a connotation [9]. Meanwhile, myth is a means to send a message or a communication system [10]. From connotation and or myth, the text's ideology can be uncovered. Aforementioned theories are used to find the meaning behind children's fantasy in the movie.

\section{Results And Discussion}

\subsection{Narrative structure in the movie Ali Zaoua: Prince de la Rue}

Narrative aspects are one of the important aspects of a movie that comprise plot, characters, and settings. The first narrative aspect is the plot. The plot in this film is linear and can be analyzed using Greimas's actantial model. Actan is the smallest narrative element in a text that aims to identify actions and meanings in it, thus creating a narration [11]. The actantial model in this film is as follows: 


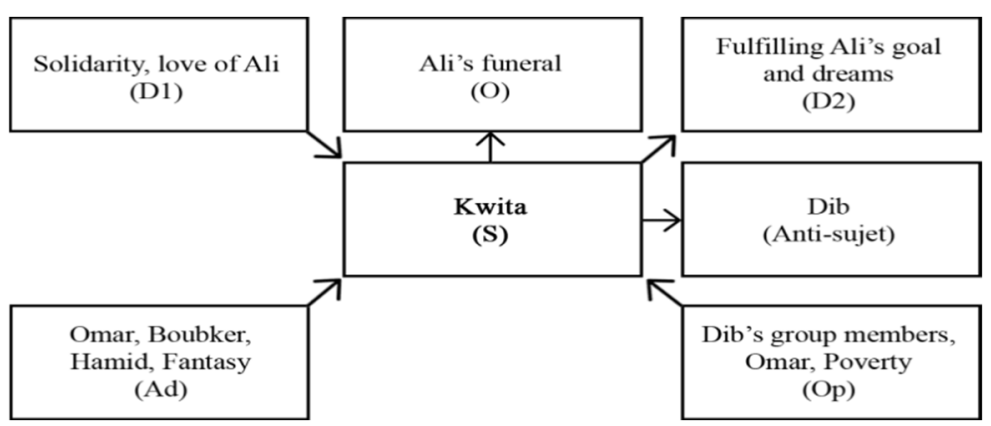

The Actantial Model of Ali Zaoua: Prince de la Rue

Explanation:

S: Sujet (Subject); O: Objet (Object); D1: Destinateur (Sender); D2: Destinataire (Receiver)

Ad: Adjuvant (Helper); Op: Opposant (Opponent); Anti-sujet: Anti-subject

The actantial model shows Kwita's position as a subject. This indicates that he has an important position in the film. At the beginning of the film, the character Ali died, therefore debunking the viewers' perception that Ali is the main character as what the film's title seems to suggest. The death of Ali also puts his funeral as an object in the plotline. Ali's funeral also became the drive that influences the flow of the story as well as the desire to make Ali's dream a reality.

Through the portrayal in the actantial model, it is shown that the characters in Ali Zaoua: Prince de la Rue can be identified in categories which as the helpers, the opponents, and the anti-subjects. The character Kwita is the most consistent character from the beginning to the end in terms of making Ali's dream to be a sailor a reality. At the beginning of the film, Kwita is depicted as a cowardly character. However, when his best friend died, Kwita turns into a brave character. Kwita's bravery was shown when he assertively rejects Dib's request to rejoin the group. This can be represented as a climax point of what happened within Kwita's self because he had successfully become a brave person like his best friend, Ali.

The other helpers are the two other friends named Boubker and Omar. Boubker is the youngest character among the others. The young age causes his indecisiveness, thus Boubker always seems to follow and abide by his friends decisions. Different from Kwita, Omar's character is the least consistent and can be categorized as both a helper and an opponent. Omar's inconsistency was shown by how he is easily influenced and emotionally triggered. However, the solidarity in Omar outpowered his selfishness in the end. Omar's ability to put aside ego and care more of his friends becomes the climax point to Omar's change of character in this film. Not only Omar and Boubker, Hamid also plays a big role in helping Kwita realizing Ali's desires. Hamid becomes an inspiration for Ali to become a sailor, thus Hamid can be seen as a connection between Ali and his dream. In fulfilling his target, Kwita also faces obstacles from several characters, such as Dib's group's members and Dib himself who is the main anti-subject. Dib's presence becomes a representation of poverty that occurs in the city of Casablanca. With the character being depicted as someone who perpetrates violence, crimes, who is authoritarian and cruel, it can be inferred that he is a reflection of the reality of street children. This is also supported by the behaviors of his group's members that seem to adopt violence.

The other narrative aspect is the setting. In the film Ali Zaoua: Prince de la Rue, the dominant geographical settings is in exterior settings or the outdoors. This represents the life of street children that do not have a place to live, therefore spending most of their times in the 
outdoors. This can be valued as a way of the text to support the depiction of their social condition. The most dominant geographical settings is port located in Casablanca. This is known from the 'Meknes Casablanca' sign that is found on a boat in the port. The port, as a recurring setting in the film, is an important geographical setting because it highly correlates with Ali's dream to become a sailor. The port becomes a place that inspires Ali's fantasies and inspires him to become a sailor. Ali's fantasy and dream then become a driving force in the film, thus indirectly, the port has a significant role. In the temporal setting, it is shown that daytime is the most dominantly portrayed setting in the film. The choice of daytime functions as a way to depict the reality of children's struggles, such as becoming vendors, that is always done in the daytime.

Narrative structure comprises plot, character, and setting in this film function to put emphasis on social issues that are meant to be shown in the entire film. The depiction of the narrative structure in the film could be a critique that would like to be shown and conveyed about the difficulties of Morocco to overcome social problems that occur in the country. The next part will elaborate on the cinematographic aspects, especially the visual and textual verbal elements.

\subsection{Visualization of Fantasies and Dreams in the film Ali Zaoua: Prince de la Rue}

Fantasy is a subject that is difficult to define but is related to imagination and the desire to make the fantasy a reality. Fantasy can be considered as pleasure, because essentially, fantasy is an effort to escape from human's condition or reality and to create a second world, that is the world of imagination. Not only to escape from reality, when correlated with desires, the fantasy becomes a way to realize dreams that are not or yet to come true [12]. Therefore, children use their understanding of what is not ordinary possible in the real world to carve out of a fantasy domain, one that is distinct for reality [13].

Children fantasy is one of the aspects that are most shown by the film Ali Zaoua: Prince de la Rue. The fantasy that is most shown through a visual aspect, that is through chalk animation, is Kwita's fantasy. The fantasy Kwita imagined focuses on a girl he met in one of the universities. The chalk animation first appeared about a sailor who is rowing a boat with tired and desperate face, when he visited the university for the second time. The picture seems to reflect Kwita's feeling about the girl he liked. In this case, the desperation he undergoes is due to a social class difference between Kwita and the girl. The social class gap becomes a barrier for Kwita to approach the girl he likes, because he realizes his position as a low-class citizen and as only a street child.

Kwita's fantasy reappeared when he saw a billboard that suddenly turns into a chalk animation of a smiling girl who is similar to the girl he likes. A smile is an expression of happiness and has the connotation as a positive response. This condition ignites hope in Kwita to be able to interact with the girl he likes. This is related to the myth that a smile can give someone hope. Besides that, a smile also plays a role in igniting the bravery in Kwita. While he used to be scared, through that illusion of a smile that seemed to be directed at him, he feels more confident in himself.

Not only Kwita, Ali who is the main character in this film also has his own fantasy that is visualized through chalk animation. Ali's fantasy is an island with two suns that is always brought up in the film. In this fantasy, there is a house on an island with two suns above it. The sun is an astronomical object that shines on earth but in connotation, it could mean hope. This is related to the myth that by hoping, someone gains the motivation to continue their life. Ali's dream about the two suns is also correlated to his wish to be a sailor because hope has 
ignited courage to dream in Ali. As a street child who lives below the poverty line, the hope that is ignited in them plays an important role in getting a better life and giving happiness.

The portrayal of two suns in Ali's fantasy is also related to Ali's trauma of the night time. Myths and visual expressions depicting solar images have long claimed a central place in the human psyche. Sun became a symbol of power and supremacy. In addition sun also being the source of all energy of life [14]. With the presence of two suns, the day will not turn to night, because the suns will take turns in shining on earth. Ali's trauma of night time is caused by his mother's job as a sex worker who always comes home late and brings home a man. That condition has made Ali hate his mother and causes him to feel uncomfortable at home and eventually chose to run away from home. His dislike to night time causes Ali to always want daylight, so he could be free from his trauma. Other than that, the question that Kwita often asks in the film, "ils se couchent dans meme temps, les deux soleils? » (do the two suns set at the same time?), seems to represent the fear in Kwita that Ali's will face his trauma again when the day turns to night. This is related to Teich's theory that the sun will provide power for humans, so that Ali can be more comfortable and recover his trauma during the day.

The visualization of chalk animation along the film is a representation of children's fantasy and imagination to the viewers. This way, the viewers seem to enter and feel the fantasy world that the children create. The fantasy imagined by the children is not only shown in visuals but also through verbal aspects. The fantasy displayed through chalk animation is very lively, so the visualization seems to realize the desires dreamed of by children. This text can be read as a criticism that basically a child has the right to get happiness whatever his social background.

\subsection{Verbalization of alienation and imagination in the Film Ali Zaoua: Prince de la Rue}

The fantasies are verbally shown through monologues, dialogues, and sound aspects. The first verbalization shown in the film is the character Kwita's monologue when he visits the university for the second time. In this case, Kwita imagines himself giving a flower to the girl he likes and asks where she lives. He also imagined having a house and wanting to have a job. The imagination happens because of a real desire and often contradicts himself [15].

Through a monologue, it can be seen that there is a huge desire in Kwita to be able to directly interact with the girl he likes. His monologue is supported by visual aspects that were shown previously which are a calk animation of flowers beside the girl. The situation further strengthens the argument that through his fantasy, Kwita seems to talk to the girl after giving her flowers. The monologue is about home and work. That shows that there is hope in Kwita to have a better life. The choice of setting, that is the university, for the second time shows a pattern related to Kwita's fantasy of having a job. The university is an educational institution, but in connotation, it is a symbol of success. In this case, success is a success in getting a job. This is related to the myth that successful people are those who have high education. Because of this, the recurring portrayal of the university as an educational institution functions to show a contrast between educated people and Kwita, the street child.

Different from Kwita whose fantasies are about the girl he likes show a teen's life in puberty, the fantasy that Boubker has is more related to family. Through the intercharacter dialogues between Boubker with Kwita and Omar, it is shown that Boubker fears a witch figure names Aïcha that exists in his fantasies. He imagined the presence of Aïcha who wanted to strangle him. His fantasy about Aïcha appeared twice in the movie, both of which in scenes in the port.

Boubker's fear of that figure can be represented as a trauma for feeling out casted and unwanted, which made him feel alienated. Like most children, Boubker needs care and attention from his surroundings, especially from his parents. That condition is also supported 
by another fantasy, which is when Boubker created a house and its parts, on the port's concrete with chalk. This represents the presence of a desire in Boubker to live in a house and his longing for a family. The house is a building that is utilized as a place of living, but a house has the connotation of a place of shelter. This is related to the myth that a house is a place of sharing love, which gives a sense of security and comfort to those who live in it. Such a condition is what Boubker dreams of as a street child without a family or a place to live.

Boubker longingness of a family is also supported by a sound aspect, which is Boubker's vocal, where he sings the song Adji Ya Wlidi three times throughout the film. That song depicts harmony and warmth that is given by a family, which is parents that always wait for and greet their children when they are coming home. This condition is the opposite of Boubker's reality because he doesn't have a home and has never felt love and attention from his parents since birth. Becoming a street child forces him to live independently, so oftentimes he longs for affection from his surroundings. This also shows how that familial institution is very important for children.

Different from Kwita and Boubker, Omar's fantasy tends to be general. Through his fantasy, he imagines having a lot of money and three cars. Omar's fantasy can be represented as a condition that is often dreamt of by street children, that is the desire to live properly with sufficient wealth to support. Money is a tool of transaction, but the connotation of money is happiness. This is related to the myth that having a lot of money can make a person happy because money can buy anything they want. As a street child, money is an alien object to Omar. By fantasizing of becoming rich, Omar tries to escape and overcome his reality as a poor street child. In reality, they live shackled in poverty and must work hard for money.

In the film Ali Zaoua: Prince de la Rue, fantasy connects two different sides of life, which are the real and imaginary life. This is a reflection of Moroccan social issue, poverty, that is the main issue. With a high level of poverty, having a better life is a hope for them who are impoverished. That reflection is represented through the many social problems the film depicts, such as poverty and family, as well as through the street children's fantasy that is to have a temporary picture of the life their desire. Therefore, verbalization of fantasy through chalk animation could be seen as a critique of social conditions in Morocco related to family problems, social class differences, and wealth [16].

\section{Conclusion}

The fantasy in the movie Ali Zaoua: Prince de la Rue is represented through children's perspective to strengthen the depiction of life's hardship. The social issues faced by the street children are represented through the dominant theme that is poverty. Aside from that, the absence of family became one of the factors that contribute to the emergence of fantasies in the children characters. The analysis about fantasy and social issues in the film Ali Zaoua: Prince de la Rue, through visual and verbal aspects, has shown that fantasies that were represented as children's imagination becomes an antithesis to the fulfillment of real-life desires. The inability to fulfill their wishes was channelled through fantasies in the form of graphics and chalk animation. Fantasies in verbal forms show a feeling of alienation as well as imaginations in children characters. The various firms that they created show a contrast to reality. This article opens a potential for further study, for instance focusing on solidarity and humanity themes through intercharacter exchanges in the film. 


\section{References}

[1] S. G. Carter, What Moroccan Cinema? A Historical and Critical Study, 1956-2006. Maryland: Lexington Books, 2009.

[2] R. Armes, "Cinemas of the Maghreb," Black Camera, vol. 1, no. 1, pp. 5-29, 2009.

[3] V. K. Orlando, Francophone Voices of the "New" Morocco in Film and Print, 1st ed. New York, USA: PALGRAVE MACMILLAN®, 2009.

[4] Haut-Commissariat au Plan et la Banque mondiale, "Pauvreté et prospérité partagée au Maroc du troisième millénaire, 2001-2014," 2017.

[5] S. L. de Moura, "The Social Construction of Street Children: Configuration and Implications," Br. J. Soc. Work, vol. 32, pp. 353-367, 2002.

[6] J. Gugler, "Ali Zaoua: The Harsh Life of Street Children and the Poetics of Childhood," J. North African Stud., vol. 12, no. 3, pp. 369-379, 2007.

[7] C. Jones, "Sufi Mysticism and Dreams in Nabil Ayouch's Ali Zaoua, Prince of the Streets," Jeun. Young People, Texts, Cult., vol. 5, no. 2, pp. 80-95, 2013.

[8] J. M. Boggs and D. W. Petrie, The Art of Watching Films, Seventh. New York: McGraw-Hill, 2008.

[9] J. Tjahjani, "Ambiguitas Genre dalam Trilogi Les Romanesques Karya Alain Robbe-Grillet," Disertasi, pp. 1-199, 2013.

[10] R. Barthes, Mythologies. Paris: Editions du Seuil, 1957.

[11] J. Palma, "Le modèle « actantiel», méthode d' analyse du politique," ÉTUDES Rech., vol. 48, pp. 1-46, 1991.

[12] R. Jackson, Fantasy: The Literature of Subversion. London and New York: Routledge, 1981.

[13] K. H. Corriveau, A. L. Kim, C. E. Schwalen, and P. L. Harris, "Abraham Lincoln and Harry Potter: Children's differentiation between historical and fantasy characters," Cognition, vol. 113, no. 2, pp. 213-225, 2009.

[14] H. Teich, Solar Light, Lunar Light: Perspectives in Human Consciousness. Genoa House, 2012.

[15] J. Zornado, "Children's Film as Social Practice," CLCWeb Comp. Lit. Cult., vol. 10, no. 2, pp. 2-10, 2008.

[16] K. Saddhono, A. Amalia, I. K. Sudarsana, and A. Indahingwati, "Multimedia Use For Beginner Level of Teaching Languages For Deaf Children: Study in Special Schools in Surakarta," in Journal of Physics: Conference Series, 2019, vol. 1254, no. 1, p. 12060. 